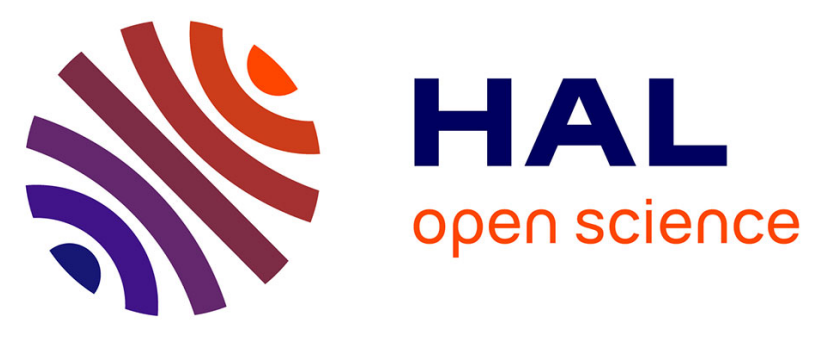

\title{
The lowest levels at Dikili Tash, northern Greece: a missing link in the Early Neolithic of Europe
}

Laurent Lespez, Zoï Tsirtsoni, Pascal Darcque, Haïdo

Koukouli-Chryssanthaki, Dimitra Malamidou, René Treuil, Robert Davidson, Georgia Kourtessi-Philippakis, Christine Oberlin

\section{To cite this version:}

Laurent Lespez, Zoï Tsirtsoni, Pascal Darcque, Haïdo Koukouli-Chryssanthaki, Dimitra Malamidou, et al.. The lowest levels at Dikili Tash, northern Greece: a missing link in the Early Neolithic of Europe. Antiquity, 2013, 87 (335), pp.30-45. 10.1017/S0003598X00048602 . hal-01484422

\section{HAL Id: hal-01484422 \\ https://hal.science/hal-01484422}

Submitted on 28 May 2020

HAL is a multi-disciplinary open access archive for the deposit and dissemination of scientific research documents, whether they are published or not. The documents may come from teaching and research institutions in France or abroad, or from public or private research centers.
L'archive ouverte pluridisciplinaire HAL, est destinée au dépôt et à la diffusion de documents scientifiques de niveau recherche, publiés ou non, émanant des établissements d'enseignement et de recherche français ou étrangers, des laboratoires publics ou privés. 


\title{
The lowest levels at Dikili Tash, northern Greece: a missing link in the Early Neolithic of Europe
}

\author{
Laurent Lespez ${ }^{1}$, Zoï Tsirtsoni ${ }^{2}$, Pascal Darcque ${ }^{2}$, \\ Haïdo Koukouli-Chryssanthaki ${ }^{3}$, Dimitra Malamidou ${ }^{4}$, René Treuil ${ }^{2}$, \\ Robert Davidson ${ }^{1}$, Georgia Kourtessi-Philippakis ${ }^{5}$ \\ \& Christine Oberlin ${ }^{6}$
}

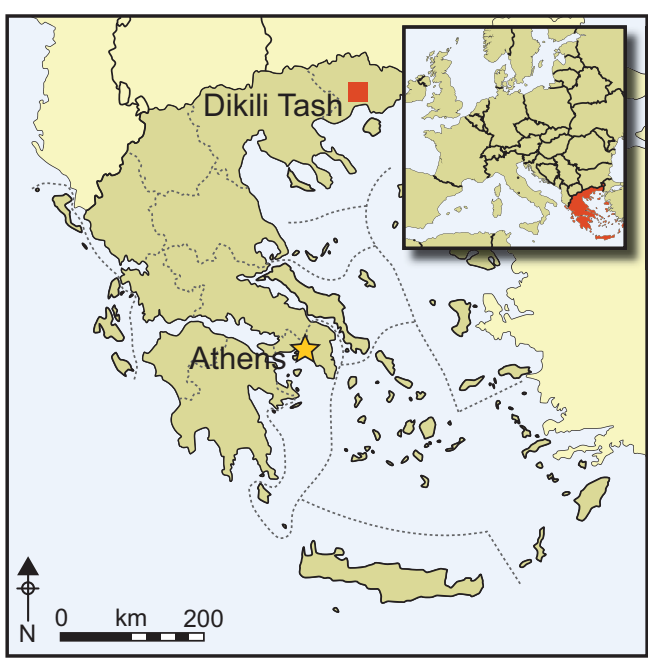

Tells famously capture the historical sequences of the earliest farmers - but digging them is not easy. With a depth of strata of $17 m$ at Dikili Tash, the earliest occupation was out of reach of a trench. But our researchers got there by coring, extending the date of the first occupation back 1000 years, and deducing, from small samples, the changing environment and possible connections with Anatolia.

Keywords: Greece, Macedonia, Early Neolithic, tell settlement, coring

1 Geophen Laboratory-LETG UMR 6554, CNRS University of Caen, Esplanade de la Paix, BP 5186, 14032 Caen Cedex, France (Email: laurent.lespez@unicaen.fr; robert.davidson@unicaen.fr)

2 UMR 7041 (Archéologies et Sciences de l'Antiquité), Maison R. Ginouvès, 21 Allée de l'Université, 92023 NanterreCedex, France (Email:zoi.tsirtsoni@mae.cnrs.fr, pascal.darcque@mae.u-paris10.fr; rene.treuil@mae.u-paris10.fr)

3 Chalkidos 4, 65004 Kavala, Greece (Email: ckoukouli@gmail.com)

$418^{\text {th }}$ Ephorate of Prehistoric and Classical Antiquities, Er. Stavrou 17, 65110 Kavala, Greece (Email: d.malamidou@free.fr)

5 Department of Archaeology, University of Athens, Campus Zografou, 15784 Athens, Greece (Email: gkphil@arch.uoa.gr)

6 Lyon Radiocarbon Laboratory-UMR 5138 (Archéométrie et Archéologie), University of Lyon 1, 40 Bd Niels Bohr, 69622 Villeurbanne, France (Email: christine.oberlin@univ-lyon1.fr) 


\section{Introduction}

The tell of Dikili Tash is located in the south-eastern part of the Drama plain, in eastern Macedonia, northern Greece. It lies some $2.5 \mathrm{~km}$ east of the ancient city of Philippi, on the outskirts of the modern town of Krinides, Kavala district. It is the biggest tell of the region, with its highest point standing at $c .15 \mathrm{~m}$ above current ground surface $(71 \mathrm{~m}$ above sea level) and extending over 4.5 hectares $(250 \times 180 \mathrm{~m}$ at its base). To its south stretched a large swamp ('Tenaghi Philippon') that occupied the lowest parts of the Drama plain until 1931.

A freshwater spring lies immediately to the north-east of the tell: until its capture in the early 1990s, the water formed a small pond here which was further drained by a small brook running along the east side of the tell (Figure 1). The site has been systematically investigated since 1961, under the auspices of the Archaeological Society at Athens and the French School at Athens. Two successive research programmes were carried out between 1961 and 2001, the first directed by D.R. Theocharis and J. Deshayes, the second by H. Koukouli-Chryssanthaki and R. Treuil. These revealed a part of the site's long stratigraphic sequence, from at least $c .5300$ to $1200 \mathrm{cal} \mathrm{BC}$ according to a series of ${ }^{14} \mathrm{C}$ and TL dates. Substantial architectural remains were brought to light from several periods, most remarkably the Neolithic (see in particular Treuil 1992; Koukouli \& Treuil 2008).

A third programme began in 2008, which aims to fully reconstruct the sequence, giving special attention to the earliest occupation (Darcque et al. 2009). The date and nature of the first human occupation represents, indeed, one of the major points of interest. The matter is crucial in the debate about the modes of adoption of the Neolithic way of life in Europe (Kotsakis 2001; Lichter 2005). If one admits that the new trends (or at least part of them) came ultimately from Anatolia and the Near East, one would expect Greek eastern Macedonia to be one of the 'entrance points', given its geographical position.

At Sitagroi, on the opposite side of the Drama plain (Renfrew et al. 1986), the first occupation level, explored in a narrow $3 \times 3 \mathrm{~m}$ trench, was hardly earlier than the earliest known Neolithic level at Dikili Tash $\left({ }^{14} \mathrm{C}\right.$ dates between $5500-5200$ cal BC). This supported the hypothesis that permanent settlements in eastern Macedonia could only have started around this date, i.e. at the end of the Aegean Middle Neolithic or the beginning of the Late Neolithic (Demoule \& Perlès 1993: 365, 388; Andreou et al. 1996: 586). At Dikili Tash, however, the virgin soil still lies some five metres below the lowest point excavated inside the tell proper (Darcque \& Tsirtsoni 2010). This suggested a possibly earlier start. But how much earlier? These depths have yet to be reached in a trench-in spite of efforts to that effect- but the exploration of the earliest phases, reported here, has been achieved by coring.

\section{The 1993 researches}

A first coring campaign in 1993 provided valuable information about the site's topography and palaeoenvironmental conditions. Ten cores established that the site's substratum, representing the flat distal part of a Pleistocene alluvial fan, was located at about 


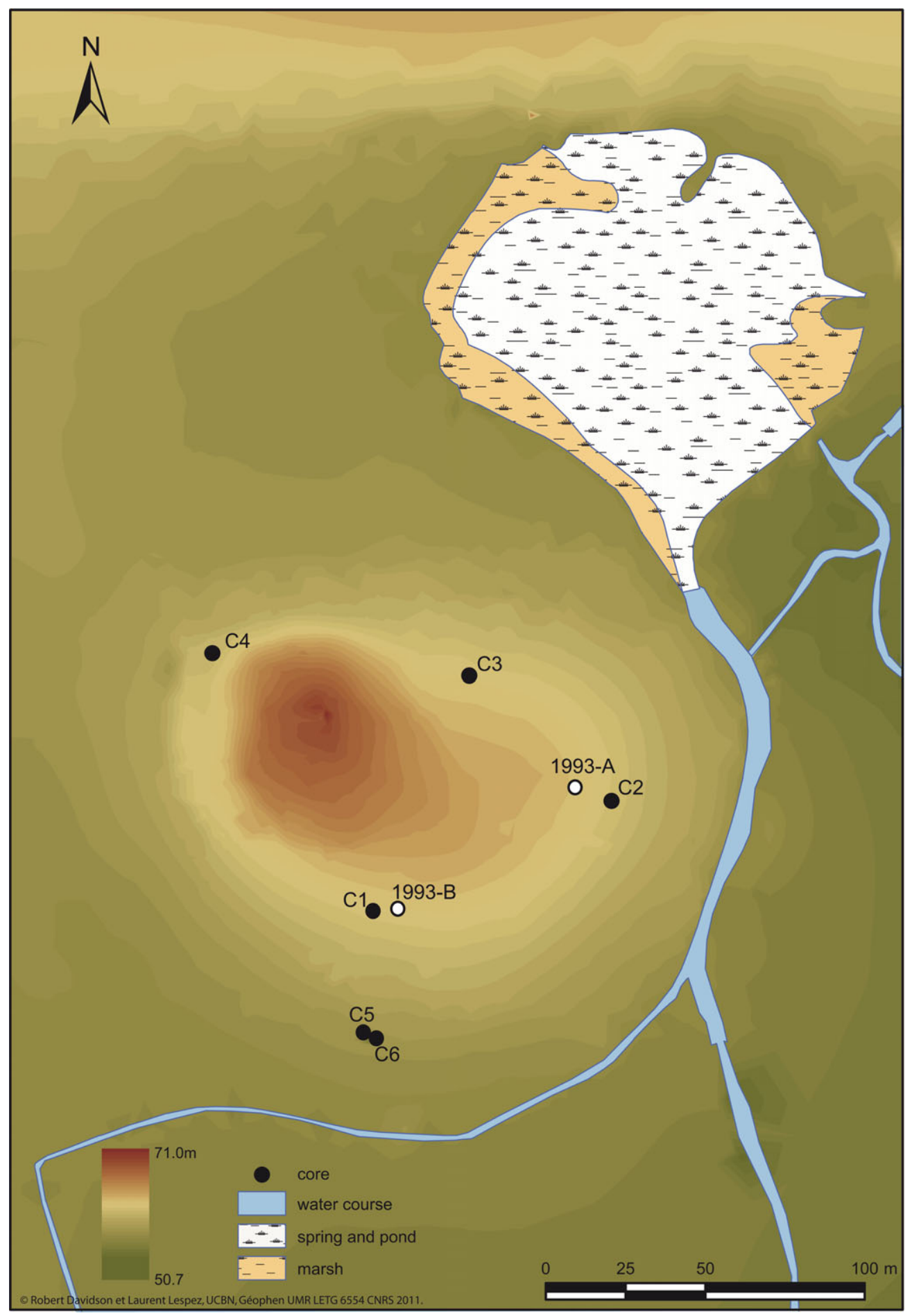

Figure 1. The tell at Dikili Tash, showing the pond and the water course running to the large Philippi swamp (not shown), as well as the location of cores (drawing: R. Davidson and L. Lespez). 
$51.5-52.5 \mathrm{~m}$ asl, i.e. approximately $17 \mathrm{~m}$ below the present tell's summit (Lespez et al. 2000). In the two main intra-site cores (Figure 1: 1993-A and 1993-B), the majority of the anthropogenic deposits consisted of successive occupation layers, from which several samples were selected for AMS dating. Nine samples were dated from core 1993-A, representing a $6 \mathrm{~m}$ depth of anthropogenic layers. The ${ }^{14} \mathrm{C}$ dates (Lyon-5010 to Lyon-5018) appeared for the most part in correct stratigraphic order: the seven upper samples, taken from layers between $c .57 .7$ and $54 \mathrm{~m}$, yielded dates between 4900/4700 and 5480/5325 cal BC (at $2 \sigma$ ), falling mostly into the Late Neolithic I (LN I) period. But the lowest one, taken from a depth of approximately $52 \mathrm{~m}$ asl, i.e. very close to the natural soil, was dated at 6592-6435 cal BC (Lyon-5018). However, its isolation, together with the fact that it was identified as an oak fragment (Quercus sp.), i.e. a very long-lived species, moderated our enthusiasm for the result. The five samples submitted next from core 1993-B confirmed and further extended the middle part of the sequence, with ${ }^{14} \mathrm{C}$ dates stretching from $c$. 5200 to 5700 cal BC (Lyon-6006 to Lyon-6010), but added no element to the earliest part; indeed, no datable material was retrieved from the lowest $1.8 \mathrm{~m}$ of the anthropogenic deposits.

\section{The 2010 cores: exploration strategy, sampling and analytical methods}

The location of the six new cores (Figure 1: C1-C6) was carefully selected. Two (C1 and C2) were taken in the vicinity of the previous cores 1993-A and 1993-B, in order to facilitate comparison between the two sets of evidence. Conversely, cores C3 and C4 were located in the northern part of the tell, which has remained thus far totally unexplored. Cores C5 and C6 completed the sequence on the tell's southern periphery. For the drillings, we used an open gouge (diameter $60 \mathrm{~mm}$, length $1 \mathrm{~m}$ ) adapted to a hand-driven percussion device (Cobra TT). After each entry, the sediment was carefully extracted from the gouge, photographed and described in the field. Each core was divided into stratigraphic units according to colour, texture and consistency, as recommended by Fedoroff \& Courty (2002) for the description of sediments in archaeological contexts. We also sorted all visible archaeological material, including charred material for ${ }^{14} \mathrm{C}$ dating. The depth coordinates of all units were re-calculated to take into account the compressing effects from the drilling device, which varied between 5 and 20 per cent. Thus, all the heights given below are in metres above sea level.

Eighteen samples from selected contexts were submitted for ${ }^{14} \mathrm{C}$ dating. These were mostly charcoals of undetermined species. The preparation of samples and the treatment of the raw results were carried out at the Radiocarbon Laboratory in Lyon, whereas the AMS measurements were made at Saclay. Considering the features of the sedimentary units found in the cores, together with what we know about the nature of the layers present at Dikili Tash from archaeological research conducted so far, we distinguished 14 recurrent layer-types, each reflecting a different archaeological and palaeoenvironmental situation. The interpretation of the stratigraphy proposed below takes into account the succession of these layers, further integrating the results of the ${ }^{14} \mathrm{C}$ dates. The presence and state of preservation of archaeological finds has been considered as well, as was their relative date whenever it could be inferred: this was especially true for some of the pottery fragments 
Table 1. The heights of horizons contacted by coring in 2010 (in metres above sea level).

\begin{tabular}{lcccc}
\hline Core & Start & End & Pleistocene substratum & Holocene palaeosol \\
\hline C1 & 61.66 & 51.66 & 52.66 & 53.66 \\
C2 & 61.13 & 51.13 & 51.82 & 52.33 \\
C3 & 61.69 & 51.69 & 52.52 & 53.26 \\
C4 & 59.98 & 53.98 & 55.30 & 55.80 \\
C5 & 55.23 & 52.23 & 52.47 & - \\
C6 & 53.60 & 52.60 & 52.90 & - \\
\hline
\end{tabular}

found in the upper levels. Sherds from the lowest parts of the cores were very small and could not be attributed to particular vessel types.

\section{Results}

\section{The original landscape}

Pleistocene formations were encountered at the base of all six cores. These had undergone profound pedogenesis during the Holocene, which resulted in the formation of a brown leached soil (Luvisol), preserved in four out of six cores (C1-C4). Its Bt horizon is well preserved, but not its surface, which has been deeply altered by human presence. The heights of both the top of the Pleistocene substratum and the Holocene palaeosol (Table 1) show a gentle but clear north-west/south-east declivity, corresponding to the natural slope of the underlying alluvial fan. The thickness $(0.5-1 \mathrm{~m})$ and well-preserved pedogenic features of the palaeosol indicate that pedogenesis was slow and took place under forest cover, consistent with the regional data from pollen analysis (Pross et al. 2009). The process could have started after the Last Glacial period, and developed across the next three millennia, between the end of the Late Dryas (9700 cal BC) and the first human settlement (6500-6400 cal BC).

\section{The earliest occupation}

The first human occupation began on this thick brown leached soil, which was eroded and transformed by human action. Occupation began earlier in the north-eastern part of the tell than in the south and north-west. This might reflect a choice to be closer to the water-spring. In core C2 (Figure 2), slightly above the palaeosol were found a small bone fragment and a tiny red-brown burnished ceramic sherd, together with charcoal dated between 6434 and $6356 \mathrm{cal} \mathrm{BC} \mathrm{(Lyon-7626).} \mathrm{In} \mathrm{core} \mathrm{C3} \mathrm{(Figure} \mathrm{3),} \mathrm{the} \mathrm{palaeosol}$ contained two charcoal fragments dated, respectively, to 6437-6262 and 6462-6393 cal BC (Lyon-7632 and 7631), i.e. in the same time range as in C2. In the same context was found a very well-preserved semi-circular end-scraper made on a flake (dimensions: $30.5 \times 32 \times 5.5 \mathrm{~mm}$ ) (Figure 4). It was made of fine-grained white chalcedony, a raw material also attested in the lithic industry from later periods at Dikili Tash (KourtessiPhilippakis 2009). This tool recalls some Pre-Pottery Neolithic (PPNB) end-scrapers from Anatolia (Balkan-Atlı 1994: 88-89 and fig. 66). Such tools are known in some Early Neolithic settlements in southern Bulgaria, but are absent in southern Greece (Perlès 2005: 


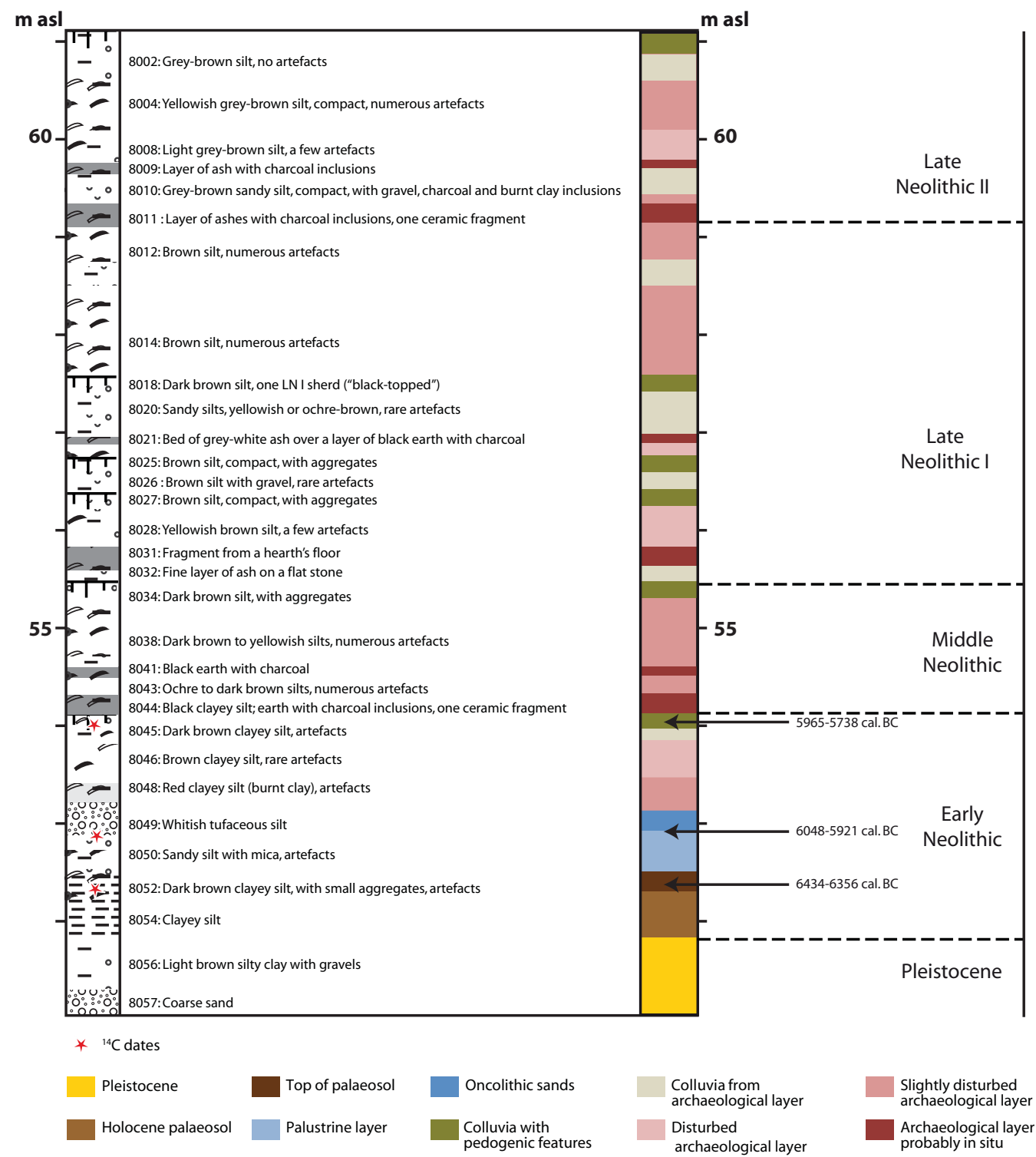

Figure 2. Core C2: sedimentary sequence and interpretation. Limits $E N-M N, M N-L N$ and LN I-II are working hypotheses.

278-81). Two distal fragments of small flakes were found in core 1993-A in a similar stratigraphic context (just above the unit that provided the seventh-millennium date, see above). The sediment that covers the palaeosol in C3 has the aspects of an occupation level, albeit slightly disturbed. Its date also falls in the range between 6378 and 6222 cal BC (Lyon-7630).

A remarkable event affected the settlement shortly after the arrival of the first inhabitants. A series of silts of palustrine origin and beds of carbonate sands and gravels (oncoliths) are 


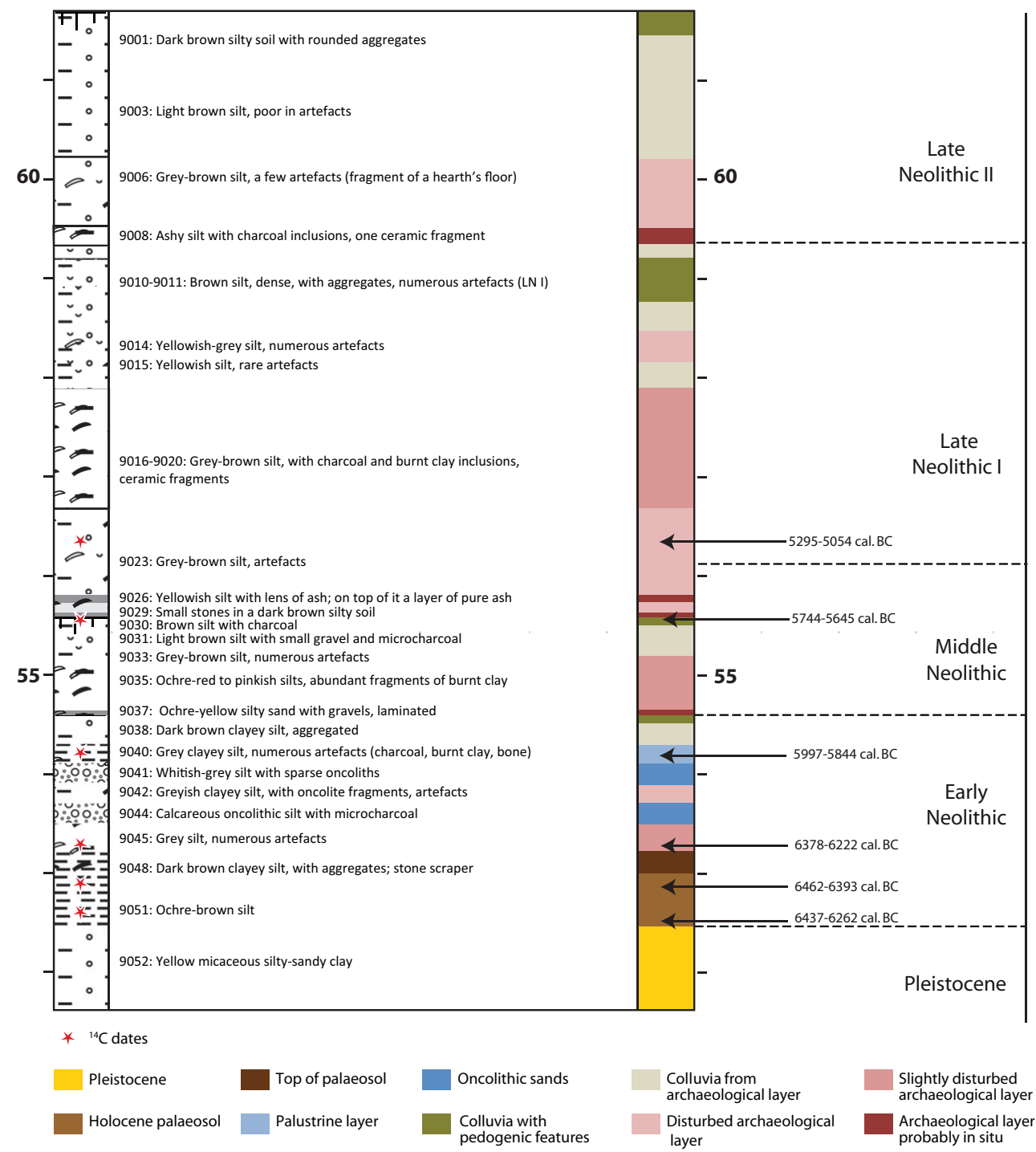

Figure 3. Core C3: sedimentary sequence and interpretation. Limits EN-MN, $M N-L N$ and LNI-II are working hypotheses.

recorded at c. 53-54m in cores C2 and C3. A layer with peat was also observed in core 1993-A at a comparable depth. This indicates a rise of the water level in the pond formed by the spring to the north-east of the site, which temporarily slowed the development of the settlement in this area. The incident is dated in the interval between 6378-6222 and 5997-5844 cal BC in C3 (Lyon-7630 and 7629), and prior to 6048-5921 cal BC in C2 (Lyon-7625). No other such event is recorded in the cores from Dikili Tash either before or after this one.

The Holocene palaeosol is completely absent in cores C5 and C6, on the southern outskirts of the tell, where the Pleistocene deposits are directly covered by colluvium. In addition, the Pleistocene substratum appears higher in C6 than in C5, i.e. at a reverse slope, 


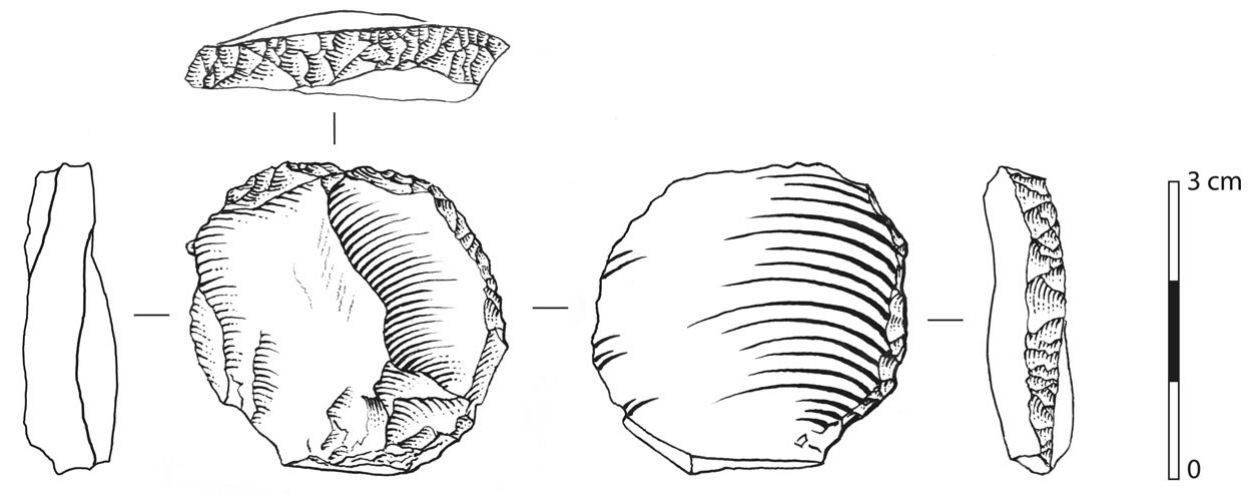

Figure 4. End-scraper found in core C3, unit 9048. Scale 1/1 (drawing: D. Molez).

suggesting that the lowest part of the sequence was removed here by digging a pit or a ditch, later filled with successive erosion deposits. According to a ${ }^{14} \mathrm{C}$ date from the base of this fill (Lyon-7923: 6011-5891 cal BC), the pit or ditch would have been dug by the end of the seventh millennium $\mathrm{BC}$, although a later date cannot be fully excluded. A connection between this soil arrangement and the rise of the water level around the settlement seems therefore possible: this could be part of a drainage system or a ditch protecting the site from a rise in the water level further south.

\section{Rearrangement and expansion of the settlement}

The date obtained from the top of the Holocene palaeosol in core C1, towards 53.3353.66m (Lyon 7617: 6100-5925 cal BC), suggests that the southern part of the future tell was occupied during this period. At the other side of the tell, in core $\mathrm{C} 4$, the first in situ occupation layer, at $55.97 \mathrm{~m}$, dates from $5971-5743 \mathrm{cal} \mathrm{BC}$ (Lyon-7635). Layers assigned to the same period are found in practically all cores, including C2 and C3. Indeed, in $\mathrm{C} 1$, a seed found in a layer of silts with charcoal and clay inclusions at $c .54 \mathrm{~m}$ provided a date of 5841-5717 cal BC (Lyon-7616). In C2, charcoal retrieved from the top of a series of occupation layers some $0.6 \mathrm{~m}$ above the level of the palustrine silts was also dated to 5965-5738 cal BC (Lyon-7624); this particular spot would therefore have been quite rapidly reoccupied. In $\mathrm{C} 3$, the marshy episode is followed by alternate erosion deposits and layers rich in burnt clay and ceramic fragments. No ${ }^{14} \mathrm{C}$ date is available, but a burnt level found slightly higher and dated to $5744-5645 \mathrm{cal} \mathrm{BC}$ (Lyon-7628) provides a terminus ante quem. It is possible then that instability lasted somewhat longer in this area than around C2. Finally, the fill of the depression in C5 records another date of 5894-5734 cal BC (Lyon-7622), at $0.2-0.6 \mathrm{~m}$ above Lyon-7923 (above). Thus, the years after $5900 \mathrm{cal} \mathrm{BC}$ appear to have been a time of expansion.

\section{Stability and development}

This is followed by a period of relative stability and development of the settlement inside its new limits, as attested by the uninterrupted succession of occupation layers in all cores. 
Table 2. Radiocarbon dates from samples collected from the 2010 cores.

\begin{tabular}{llllllll}
\hline Inv. no. & Height $(\mathbf{m}$ asl $)$ & Sample & Exp. Lab no. & Meas. Lab no. & BP date & \pm BP & cal BC date $(2 \sigma)$ \\
\hline Core 1 & & & & & & & \\
$1051-001$ & $54.66-54.51$ & charcoal & Lyon-7615 & SacA-22576 & 6665 & 35 & $5636-5533$ \\
$1056-001$ & $54.11-54.03$ & seeds & Lyon-7616 & SacA-22577 & 6890 & 35 & $5841-5717$ \\
$1059-002$ & $53.66-53.33$ & charcoal & Lyon-7617 & SacA-22578 & 7165 & 40 & $6100-5925$ \\
Core 2 & & & & & & & \\
$8045-001$ & $54.13-53.82$ & charcoal & Lyon-7624 & SacA-22585 & 6950 & 35 & $5965-5738$ \\
$8050-001$ & $53.01-52.77$ & charcoal & Lyon-7625 & SacA-22586 & 7115 & 35 & $6048-5921$ \\
$8052-001$ & $52.53-52.39$ & charcoal & Lyon-7626 & SacA-22587 & 7495 & 35 & $6434-6356$ \\
Core 3 & & & & & & & \\
$9023-001$ & $56.33-56.15$ & charcoal & Lyon-7627 & SacA-22588 & 6210 & 35 & $5295-5054$ \\
$9030-001$ & $55.58-55.54$ & charcoal & Lyon-7628 & SacA-22589 & 6825 & 35 & $5744-5645$ \\
$9040-001$ & $54.28-54.08$ & charcoal & Lyon-7629 & SacA-22590 & 7040 & 35 & $5997-5844$ \\
$9045-001$ & $53.53-53.26$ & charcoal & Lyon-7630 & SacA-22591 & 7405 & 35 & $6378-6222$ \\
$9048-001$ & $52.97-52.74$ & charcoal & Lyon-7631 & SacA-22592 & 7560 & 35 & $6462-6393$ \\
$9051-001$ & $52.69-52.52$ & charcoal & Lyon-7632 & SacA-22593 & 7505 & 35 & $6437-6262$ \\
Core 4 & & & & & & & \\
$10011-001$ & $57.77-57.44$ & charcoal & Lyon-7633 & SacA-22594 & 6530 & 35 & $5607-5384$ \\
$10021-001$ & $56.00-55.98$ & charcoal & Lyon-7634 & SacA-22595 & 6230 & 35 & $5302-5067$ \\
$10023-001$ & $55.97-55.93$ & charcoal & Lyon-7635 & SacA-22596 & 6960 & 35 & $5971-5743$ \\
Core 5 & & & & & & & \\
$2906-002$ & $53.85-53.45$ & charcoal & Lyon-7622 & SacA-22583 & 6940 & 35 & $5894-5734$ \\
$2908-001$ & $53.23-52.90$ & bone & Lyon-7923 & SacA-23911 & 7070 & 35 & $6011-5891$ \\
Core 6 & & & & & & & \\
$2950-001$ & $53.60-52.86$ & charcoal & Lyon-7623 & SacA-22584 & 6310 & 35 & $5358-5217$ \\
\hline
\end{tabular}

In $\mathrm{C} 1$, a series of layers rich in burnt clay inclusions is found between 54.11 and $54.51 \mathrm{~m}$, followed by a clear layer of ash and charcoal, dated to 5636-5533 cal BC (Lyon-7615), representing the base of a thick destruction level. In $\mathrm{C} 2$, the sediments above $54.13 \mathrm{~m}$ are of similar nature, but no ${ }^{14} \mathrm{C}$ dates are available. In $\mathrm{C} 4$, a charcoal at $57.44-57.77 \mathrm{~m}$, i.e. c. $1.5 \mathrm{~m}$ above the first occupation layer, yielded a date of 5607-5384 cal BC (Lyon7633); a sample from a lower unit dated to 5302-5067 cal BC (Lyon-7634) was probably reworked. In $\mathrm{C} 3$, the last sample comes from a slightly disturbed occupation layer dated to 5295-5054 cal BC (Lyon-7627). Colluvia dating to the same period were also found in C6 (Lyon-7623). No dating samples were submitted from the upper parts of the cores, since they contained sufficient diagnostic sherds to indicate that these were the Late Neolithic LN I and LN II layers; both these periods are well-dated from reliable excavated contexts.

\section{Discussion}

\section{The Neolithic sequence at Dikili Tash}

The eighteen ${ }^{14} \mathrm{C}$ dates from the 2010 cores are of high precision (error 30-35 years BP); calibrated at $2 \sigma$ (at $95 \%$ probability), they give calendar ages within a range of 150 to 250 


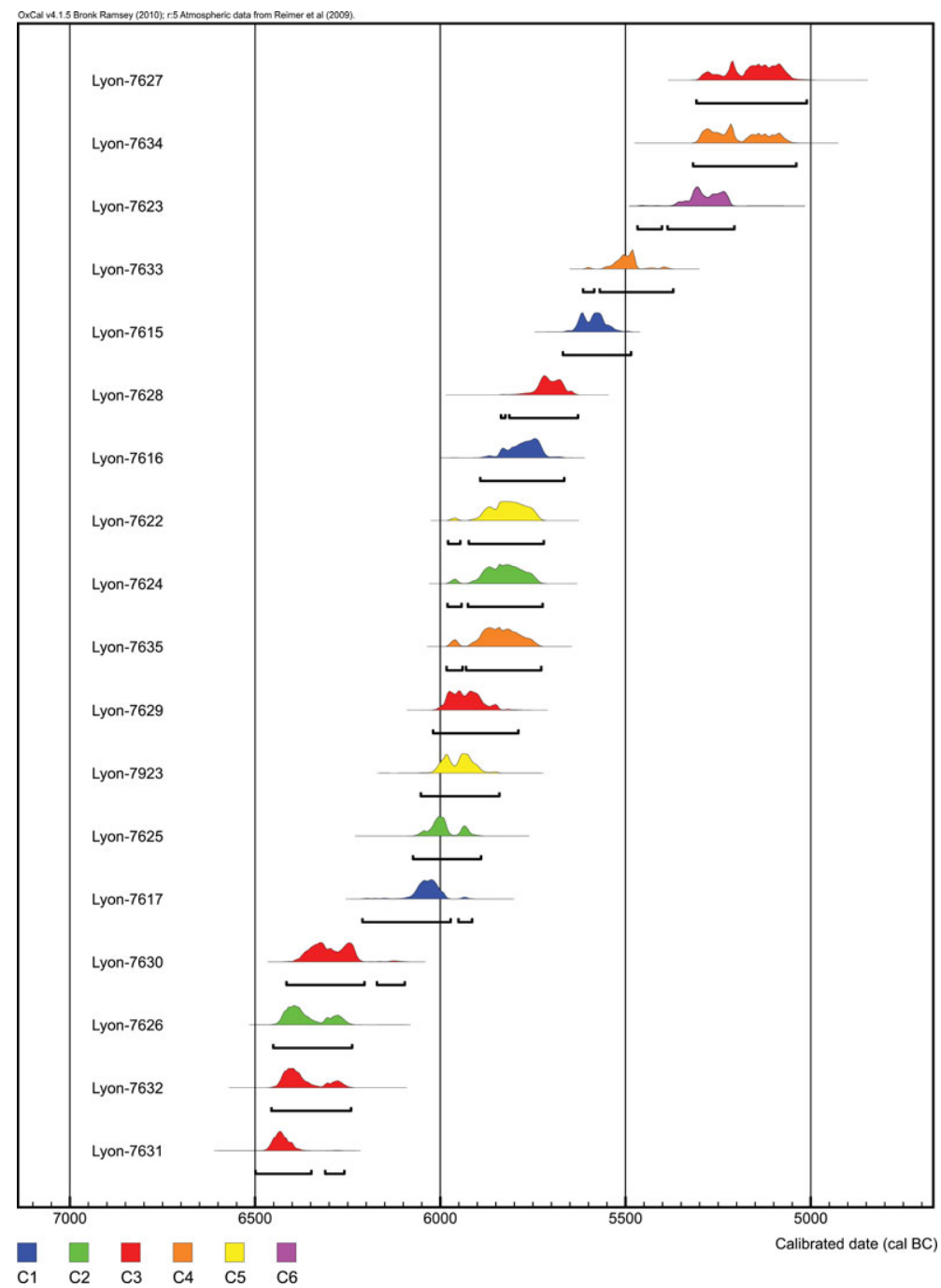

Figure 5. Diagram (OxCal v. 4.1.5) with ${ }^{14} \mathrm{C}$ dates from the 2010 cores ordered according to their BP values. Colours correspond to different cores (see Table 2).

years, sometimes even less (Table 2 and Figure 5). With only one exception, they agree fully with the stratigraphic order in each core, are consistent with each other, and agree well with the sediment analysis. A sufficient number of artefacts support and complete the chronology.

Eight dates (Figure 5: Lyon-7631 to 7629) fall in the interval between roughly 6500 and $5900 \mathrm{cal} \mathrm{BC}$, with which we can now securely associate the Lyon-5018 date from core 1993-A. These correspond to the Early Neolithic period at Dikili Tash, missing up to now.

A first cluster of dates, between 6400 and $6200 \mathrm{cal} \mathrm{BC}$, represents the start of the settlement, in the north-eastern part of the future tell. Considering the fact that all the dates are from charcoal, possibly belonging to trees of a certain age, one could presume that the 


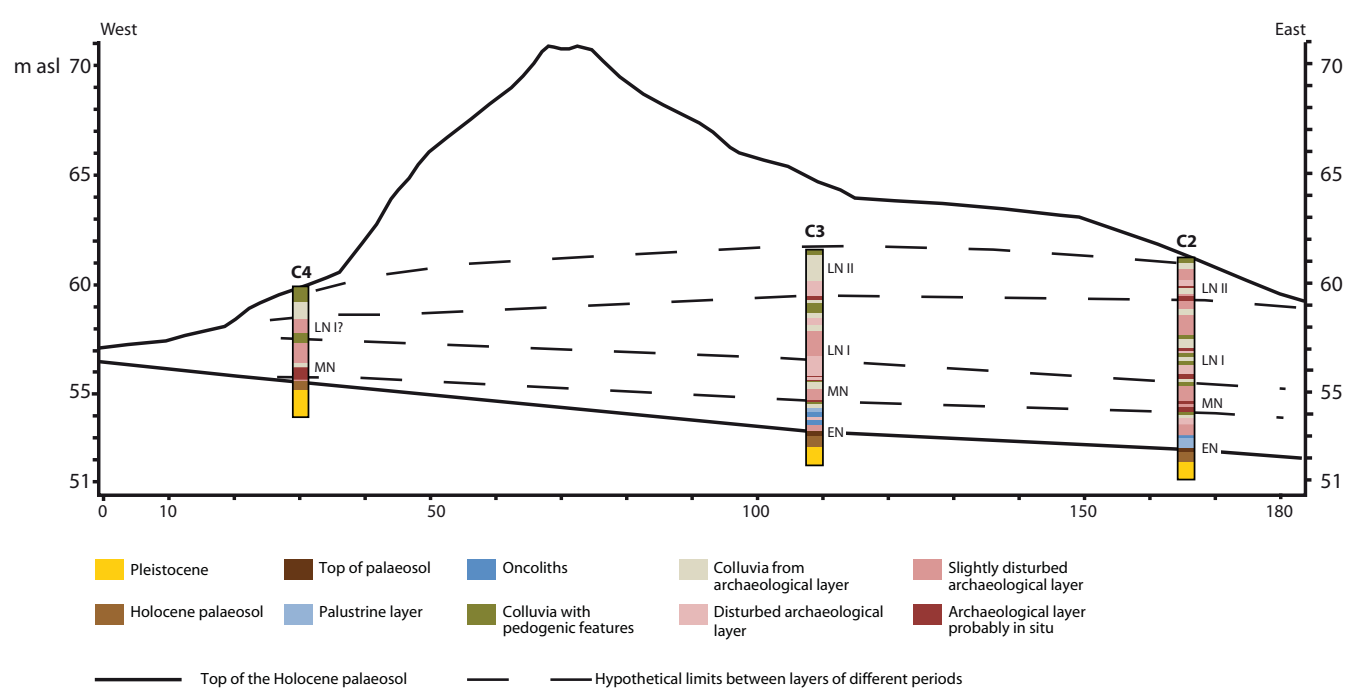

Figure 6. Transect along the axis of cores C4, C3 and C2.

true beginning is closer to the younger end of this interval. A second cluster, from 6100 to $5900 / 5850 \mathrm{cal}$ BC, corresponds to the movement of the settlement towards the south, then back again to the east and north. The latter partly overlaps with the earliest dates from the next period, indicating a perfectly continuous transition.

The years from c. 5900/5800 to 5400 cal BC represent the Middle Neolithic period, as defined in the Greek Aegean relative chronology. Seven ${ }^{14} \mathrm{C}$ dates fall within this interval (Figure 5: Lyon-7635 to 7633); we can add to them the Lyon-6010 date from core 1993-B. This is a phase of further expansion and stabilisation of the settlement, as shown by the spatial distribution of the related deposits (Figures $6 \& 7$ ). The thickness of the deposits is now greater to the north (c. $2 \mathrm{~m}$ in cores C3 and C4) than in the south ( $1 \mathrm{~m}$ in C1 and C2), whereas the total height of the mound would not exceed 3 to $4 \mathrm{~m}$; its profile would therefore be similar to that of the contemporary Thessalian tells (magoules).

This tendency seems to be reversed in the Late Neolithic I period, from $5400 \mathrm{cal}$ BC onwards, when deposits start to be thicker in the centre and to the south than to the north. The successive anthropogenic layers reach a thickness of 6 to $10 \mathrm{~m}$ for the Late Neolithic I and II, thus giving the tell most of its actual size and form. It is only at this period that the tell of Dikili Tash becomes a landmark (Darcque \& Tsirtsoni 2010).

\section{Regional perspective: a lacuna filled}

This investigation fills the Early Neolithic gap in this part of northern Greece. In our present state of knowledge and at the current level of precision of ${ }^{14} \mathrm{C}$ dates, the earliest occupation at Dikili Tash seems, indeed, more or less contemporary with the earliest Neolithic levels on sites from Greek Western Macedonia and Thessaly (Nea Nikomedeia, MavropigiFyllotsaïri, Paliambela, Theopetra, Achilleion, Sesklo, Argissa; see Perlès 2001: 100-106, table 6.1; Karamitrou-Mentesidi 2009: 117-25; Papathanasiou 2011: 258; Maniatis et al. forthcoming), and slightly earlier than those from southern Bulgaria (Kovačevo, Čavdar, 


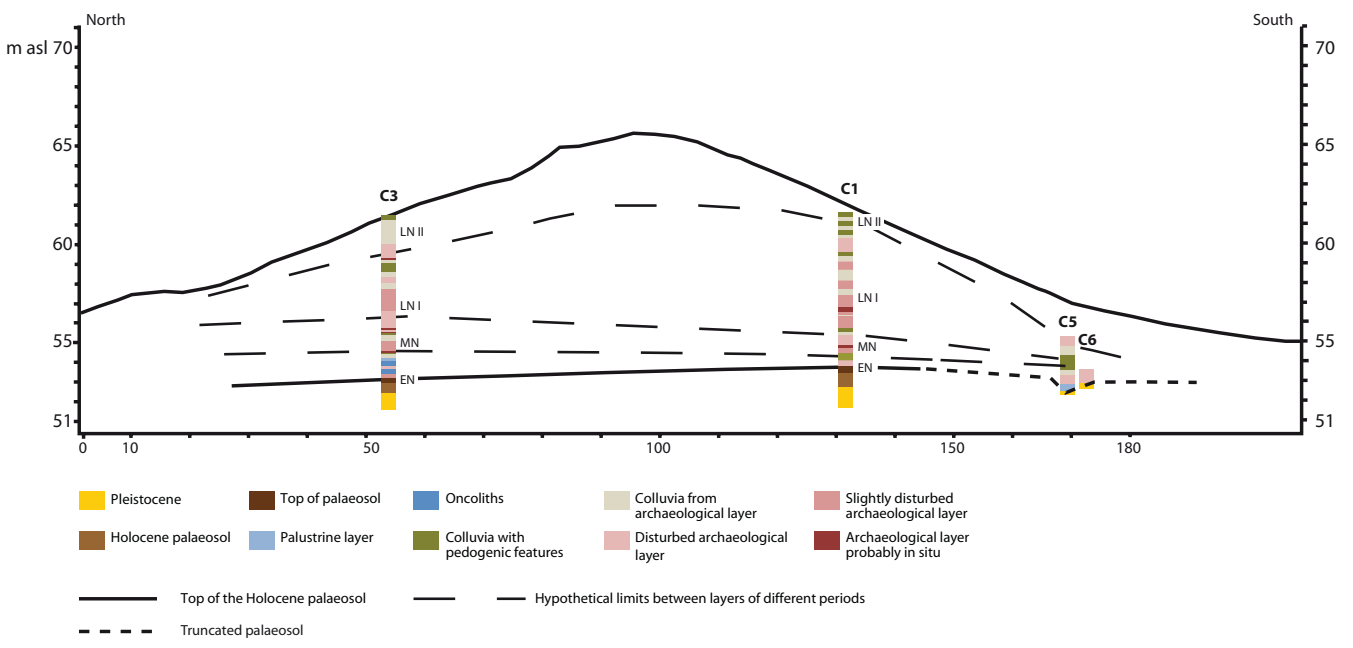

Figure 7. Transect along the axis of cores C3, C1, C5 and C6.

Gălăbnik, Karanovo, Azmak, Stara Zagora, starting around 6200 cal BC: Reingruber \& Thissen 2005; Higham et al. 2011: 1078-79). This evidence agrees with the data from Hoca Çeşme and Makri, in coastal Thrace, and Uğurlu, on the opposite island of Gökçeada (Imbros), where permanent settlements also seem to start around 6500-6200 cal BC (Reingruber \& Thissen 2005: 322; Ammermann et al. 2008: 148; Erdoğu 2011: 50) (Figure 8).

Only two other Early Neolithic open-air settlements are known in Greece in the area between the rivers Evros to the east and Axios to the west: Liti (sites I-III, 700 to $1500 \mathrm{~m}$ distant from each other) and Mikri Volvi, both in central Macedonia (Lioutas \& Kotsos 2006; Tzanavari \& Filis 2009). There are no ${ }^{14} \mathrm{C}$ dates, but according to the pottery finds, they should both be assigned to the later stage of the period and the transition to the Middle Neolithic. It now appears that the scarcity of early open-air settlements in this area should be attributed to problems in taphonomy rather than to a real absence.

In the broader region around Dikili Tash, several sites are occupied in the time range between 5900/5850 and 5400 cal BC (Görsdorf \& Boyadziev 1996; Maniatis 2002; Roodenberg et al. 2003; Reingruber \& Thissen 2005; Karul \& Avci 2011; Leshtakov et al. 2011; Maniatis \& Fakorellis 2012). These are, on the one hand, sites where settlement continues from the preceding period (Ilıpınar, Menteşe, Aktopraklık, Makri, Karanovo, Azmak, Stara Zagora, Cavdar, Gălăbnik, Anzabegovo, Paliambela, Otzaki, Argissa, Sesklo, Achilleion, Theopetra, Youra) and, on the other hand, sites that were settled for the first time (Aşağı Pınar, Yabălkovo, Elešnica, Bălgarčevo, Limenaria, Stavroupoli, Vršnik, Servia, Platia Magoula Zarkou, Agios Petros). Dikili Tash clearly belongs to the first group. It appears to be one of those places that humans, once installed, would be reluctant to quit.

\section{Dikili Tash and the 8200 cal BP event}

The rise of the water level recorded in cores C2 and C3 directly above the first evidence for human settlement in $c .6200 \mathrm{cal} \mathrm{BC}$ could be a local response to the global $8200 \mathrm{cal}$ 


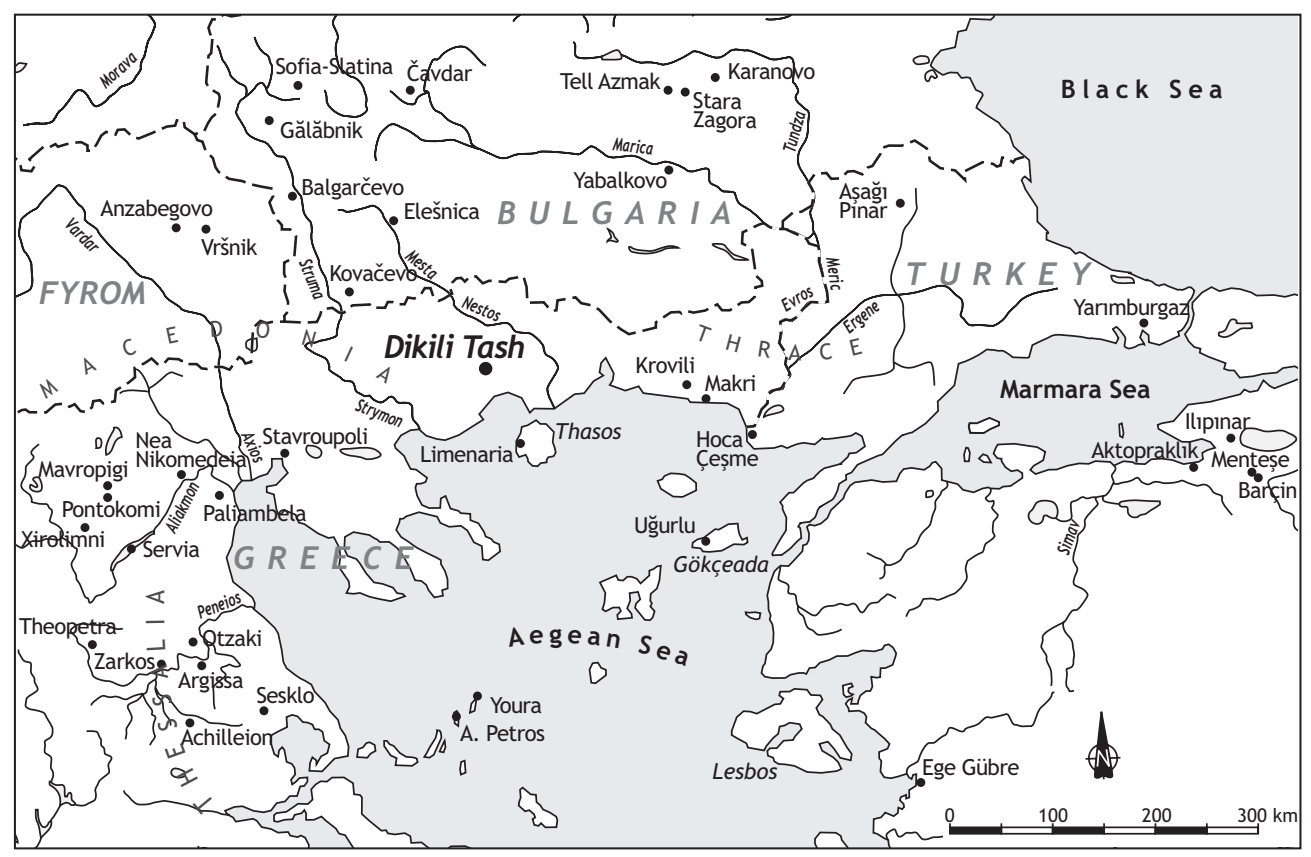

Figure 8. Neolithic sites in the North Aegean and neighbouring areas with ${ }^{14} \mathrm{C}$ dates between 6500 and 5500 cal BC (at $2 \sigma)$.

BP climatic event (Mayewski et al. 2004; Berger \& Guilaine 2009). Recent studies on the Holocene palaeoclimatic evolution in the northern Aegean, based on evidence from deep sea cores (Kotthoff et al. 2008) and from lake sediments in the southern Balkans, including the Philippi plain itself (Pross et al. 2009; Peyron et al. 2011), confirm that a major climatic change took place between 8.4 and $8.1 \mathrm{ka} \mathrm{cal} \mathrm{BP,} \mathrm{i.e.} \mathrm{between} 6450$ and $6150 \mathrm{cal}$ BC. They indicate a general cooling of the atmosphere, further accompanied by a decrease of annual rainfall by 800 to $600 \mathrm{~mm}$. The phenomenon is more intense in winter periods (mean temperatures lowered by more than $4^{\circ} \mathrm{C}$ in winter, less than $2^{\circ} \mathrm{C}$ in summer).

A deficiency in rainfall should normally provoke a lowering of the level in water tables and lakes. But things are obviously more complex. A rise in summer rainfall of only $75 \mathrm{~mm}$ (Peyron et al. 2011), combined with the decrease in temperature and the reduction of evapotranspiration, would have maintained groundwater at a high level. This is further supported by the increase, registered in cores from the former Philippi swamp, of taxa from Gramineae (grasses) and Cyperaceae (sedges) restricted to humid zones, not included in the climate models (Pross et al. 2009). Palaeoenvironmental studies from Early Neolithic and Middle Neolithic sites in Thessaly also suggest flood flows loaded with silts, thus pointing towards high hydrological activity during this period (Van Andel \& Runnels 1995), whereas on Corfou, the settlement of Sidari is cut by deep fluvial flows attributed to the years around the rapid climatic change (Berger \& Guilaine 2009). 
The impact of all these changes on human settlement at Dikili Tash is not easy to determine. The decrease in mean annual temperatures would certainly have had consequences for the life of these early farmers. But the presence of archaeological artefacts at the base of the four main cores and the ${ }^{14} \mathrm{C}$ dates that accompany them prove that occupation started before and lasted well after $6250 \mathrm{cal}$ BC. At most they indicate a temporary shrinkage, or more probably a movement of the settlement towards drier parts of the site. This would agree with some observations made in the Thessalian floodplain, where layers of silts are regularly stratified between the occupation layers. The above remarks underline the necessity to learn more about settlement patterns and palaeoclimatic evolution in the northern Aegean in the years around the $8200 \mathrm{cal} \mathrm{BP}$ event, before looking for a possible link with the development of the first Neolithic societies (Weninger et al. 2006).

\section{Conclusion}

The discovery of Early and Middle Neolithic layers at the base of the tell at Dikili Tash puts an end to the long debate about the start of permanent settlements in Greek Eastern Macedonia and provides some interesting clues about the processes of establishment of a new way of life in local conditions (Lichter 2005; Efstratiou 2007; Kotsakis 2007). The area is no longer a 'blank space' in the distribution maps of the Aegean and European Early Neolithic (Figure 8). Evidence from Dikili Tash seems to reinforce the hypothesis of an east-west spread of the Neolithic through north-western Anatolia and the north Aegean, bringing at the same time an important re-adjustment to the chronology of events. Ongoing excavations in the site should allow checking and further refining of this scenario.

\section{Acknowledgements}

We express our gratitude to all the institutions that support, directly or indirectly, the research carried out at Dikili Tash: the Archaeological Society and the French School at Athens, the French Ministry of Foreign and European Affairs, the Institute for Aegean Prehistory (INSTAP), the National Geographic Society, the municipality of Philippi, the French National Centre for Scientific Research (CNRS) and the French National Research Agency (ANR). We also thank for their help the heads of the Ephorate of Prehistoric and Classical Antiquities of Kavala (Greek Ministry of Culture). The study of the earliest occupation levels at Dikili Tash enters the frame of the international research project Archeo-Med (action PaleoMex, Mediterranean Integrated Studies at Regional and Local Scales [Mistrals]). The anthracological identification of the 1993 samples was made by Stéphanie Thiébault (CNRS-UMR 7209, Paris), whom we thank sincerely. Special thanks to Becky Miller for revising the original manuscript, and also to the two Antiquity reviewers for their useful comments.

\section{References}

Ammermann, A.J., N. Efstratiou, M. Ntinou, K. PaVlopoulos, R. Gabrielli, K.D. Thomas \& M.A. MANNINO. 2008. Finding the early Neolithic in Aegean Thrace: the use of cores. Antiquity 82: $139-50$.
ANDREOU, S., M. Fotiadis \& K. KotSAKIs. 1996. Review of Aegean Prehistory V: the Neolithic and Bronze Age of Northern Greece. American Journal of Archaeology 100: 537-97.

Balkan-AtLi, N. 1994. La Néolithisation de l'Anatolie. Paris: De Boccard. 
Berger, J.-F. \& J. Guilaine. 2009. The $8200 \mathrm{cal}$ BP abrupt environmental change and the Neolithic transition: a Mediterranean perspective. Quaternary International 200: 31-49.

DARCQUe, P. \& Z. TSIRTSONI. 2010. Evidence from Dikili Tash (Eastern Macedonia, Greece) and the tell issue, in S. Hansen (ed.) Leben auf dem Tell als soziale Praxis, Beiträge des internationalen Symposiums in Berlin vom 26-27 Februar 2007 (Kolloquien zur Vor- und Frühgeschichte 14): 55-69. Bonn: Rudolf Habelt.

Darcque, P., H. Koukouli- ChryssanthaKi, D. Malamidou \& Z. TsirTsOni. 2009. Rapport sur les travaux de l'École française d'Athènes en 2008: Dikili Tash. Bulletin de Correspondance Hellénique 133: 529-41.

Demoule, J.-P. \& C. Perlès. 1993. The Greek Neolithic: a new review. Journal of World Prehistory 7: 355-416.

Efstratiou, N. 2007. The beginning of the Neolithic in Greece: probing the limits of a 'grand' narrative, in S. Antoniadou \& A. Pace (ed.) Mediterranean crossroads: 123-38. Athens: Pierides Foundation.

ERDOĞU, B. 2011. A premilinary report from the 2009 and 2010 field seasons at Uğurlu on the island of Gökçeada. Anatolica 37: 45-65.

Fedoroff, N. \& M.-A. CourTy. 2002. Paléosols et sols reliques, in J.-C. Miskovsky (ed.) Géologie de la Préhistoire: 277-316. Perpignan: Presses Universitaires de Perpignan, GéoPré.

GÖRSDORF, J. \& J. BOJADŽIEV. 1996. Zur absoluten Chronologie der bulgarischen Urgeschichte. Eurasia Antiqua 2: 105-73.

Higham, T.F.G., C. Bronk Ramsey, F. Brock, D. BAKER \& P. DITCHFIELD. 2011. Radiocarbon dates from the Oxford AMS System: Archaeometry datelist 34. Archaeometry 53: 1067-84.

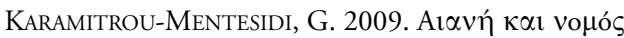

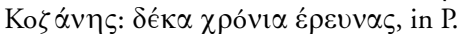
Adam-Veleni \& K. Tzanavari (ed.) To

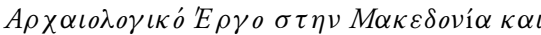

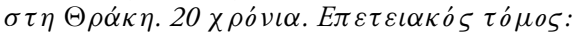
105-26. Thessaloniki: Ministry of Culture \& University of Thessaloniki.

Karul, N. \& M.B. AvCI. 2011. Neolithic communities in the eastern Marmara region: Aktopraklık C. Anatolica 37: 1-15.

KoTSAKIS, K. 2001. Mesolithic to Neolithic in Greece: continuity, discontinuity or change of course? Documenta Prehistorica 28: 63-73.

- 2007. A bridge too far, essentialist concepts in Greek archaeology, in S. Antoniadou \& A. Pace (ed.) Mediterranean crossroads: 109-21. Athens: Pierides Foundation.
Kotthoff, U., J. Pross, U.C. Müller, O. Peyron, G. SCHMiedl, H. Schulz \& A. Bordon. 2008.

Climate dynamics in the borderlands of the Aegean Sea during formation of Sapropel S1 deduced from a marine pollen record. Quaternary Science Reviews 27: $832-45$.

Koukouli-Chryssanthaki, C. \& R. Treuil. 2008. Dikili Tash, village préhistorique de Macédoine orientale. Recherches franco-helléniques dirigées par la Société archéologique d'Athènes et l'École française d'Athènes (1986-2001) (Bibliothèque de la Société archéologique d'Athènes 254). Athens: Société archéologique d'Athènes.

KourTessi-PhilipPAKIS, G. 2009. Lithics in the Neolithic of Northern Greece: territorial perspectives from an off-obsidian area. Documenta Praehistorica 36: 305-12.

Leshtakov, K., N. Todorova, V. Petrova \& G. KaCAROV. 2011. Селище от ранния неолит, км 28+650-29+000 по трасето на АМ «Марица» в землището на с. Ябълково, об-на Димитровград, обл. Хасково. Археологически Открития и Разкопки през 2011 2.

Lespez, L., R. Dalongeville, C. Noirel-Shutz, J.-P. Suc, C. Koukouli-Chryssanthaki \& R. Treuil. 2000. Les paléoenvironnements du site préhistorique de Dikili Tash (Macédoine orientale, Grèce). Bulletin de Correspondance Hellénique 124: 413-34.

LICHTER, C. (ed.) 2005. How did farming reach Europe? Anatolian-European relations from the second half of the 7 th through the first half of the 6th millennium cal $B C$ : proceedings of the International Workshop, Istanbul, 20-22 May 2004 (BYZAS 2). Istanbul: Ege Yayinlari.

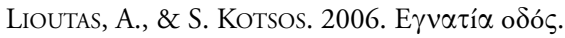

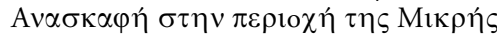

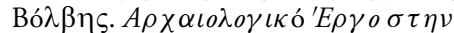

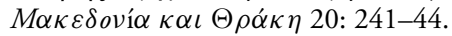

Maniatis, G. 2002. A $\pi$ o $\tau \varepsilon \lambda \varepsilon \dot{\varepsilon} \sigma \mu \alpha \tau \alpha$

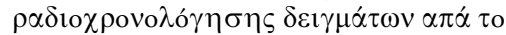

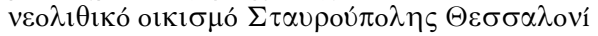
$\kappa \eta \varsigma$, in D. Grammenos \& S. Kotsos (ed.) $\Sigma \omega \sigma \tau \iota \kappa \dot{\varepsilon} \varsigma \alpha \nu \alpha \sigma \kappa \alpha \varphi \dot{\varepsilon} \varsigma \sigma \tau o \nu \varepsilon o \lambda \iota \theta \iota \kappa o ́$

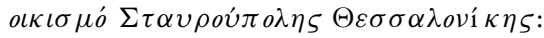
847. Thessaloniki: Archaeological Institute of Northern Greece.

Maniatis, G. \& G. FAKORELlis. 2012. Xpovo $\lambda$ ó $\gamma \eta\rceil \eta$

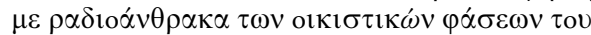

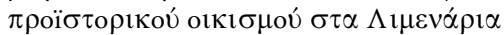

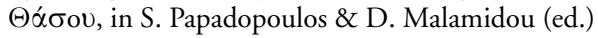
$\Delta \dot{\varepsilon} \kappa \alpha \chi \rho o ́ v \iota \alpha \alpha \nu \alpha \sigma \kappa \alpha \varphi \iota \kappa \dot{\eta} \varsigma \dot{\varepsilon} \rho \varepsilon v \nu \alpha \varsigma \sigma \tau o \nu$

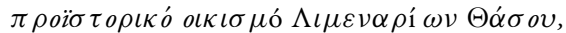

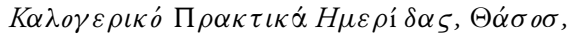
11 Iov $\lambda$ i ov 2003: 275-91. Thessaloniki: Ministry of Culture. 
Maniatis, G., K. Kotsakis \& P. Halstead.

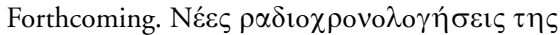

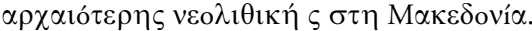

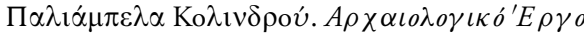
$\sigma \tau \eta \nu M \alpha \kappa \varepsilon \delta o \nu i \alpha \kappa \alpha \iota \Theta \rho \alpha ́ \alpha \eta 25$.

MAYEWSKI, P.A., E.E. ROHLING, J.C. STAGER, W. Karlén, K.A. MaAsCh, L.D. MeEKer, E.A. Meyerson, F. Gasse, S. van Kreveld, K. Holmgren, J. LeE-Thorph, G. RosQVist, F. RACK, M. STAUbWASSER, R.R. SCHNEIDER \& E.J. STEIG. 2004. Holocene climate variability. Quaternary Research 62: 243-55.

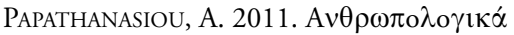

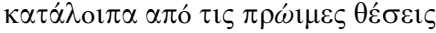

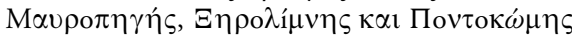

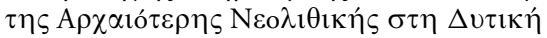
$\mathrm{M} \alpha \kappa \varepsilon \delta o v^{\prime} \alpha$, in G. Karamitrou-Mentesidi (ed.) To

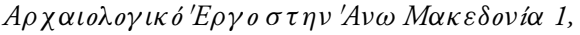
2009: 257-74. Aiani: Ministry of Culture \& Archaeological Museum of Aiani.

PERLÈs, C. 2001. The Early Neolithic in Greece: the first farmers in Europe. Cambridge: Cambridge University Press.

- 2005. From the Near East to Greece: let's reverse the focus. Cultural elements that didn't transfer, in C. Lichter (ed.) How did farming reach Europe? Anatolian-European relations from the second half of the 7 th through the first half of the 6th millennium cal $B C$ (BYZAS 2): 275-90. Istanbul: Ege Yayinlari.

Peyron, O., S. Goring, I. Dormoy, U. Kotthoff, J. Pross, J.-L. DE Beaulieu, R.

DRESCHER-SCHNEIDER, B. VANNIÈRE \& M. MAGNY. 2011. Holocene seasonality changes in the central Mediterranean region reconstructed from the pollen sequences of Lake Accesa (Italy) and Tenaghi Philippon (Greece). The Holocene 21: 131-46.

Pross, J., U. Kotthoff, U.C. Müller, O. Peyron, I. Dormoy, G. Schmiedl, S. Kalaitzidis \& A.M. SMITH. 2009. Massive perturbation in terrestrial ecosystems of the Eastern Mediterranean region associated with the $8.2 \mathrm{kyr}$ B.P. climatic event. Geology 37: 887-90.
Reingruber, A. \& L. Thissen. $2005 .{ }^{14} \mathrm{C}$ database for the Aegean catchment (Eastern Greece, Southern Balkans and Western Turkey) 10,000-5500 cal BC, in C. Lichter (ed.) How did farming reach Europe? Anatolian-European relations from the second half of the 7 th through the first half of the 6th millennium cal $B C$ (BYZAS 2): 295-327. Istanbul: Ege Yayinlari.

Renfrew, C., M. Gimbutas \& E. Elster (ed.) 1986. Excavations at Sitagroi, a prehistoric village in northeast Greece volume 1 (Monumenta Archeologica 13). Los Angeles (CA): Institute of Archaeology at UCLA.

RoodenberG, J., A. Van As, L. Jacobs \& M.H. WIJNEN. 2003. Early settlement in the plain of Yenişehir (NW Anatolia). The basal occupation layers at Menteşe. Anatolica 29: 17-59.

Treuil, R. (ed.) 1992. Dikili Tash, village préhistorique de Macédoine orientale, I. Fouilles de Jean Deshayes (1961-1975) (Bulletin de Correspondance Hellénique Supplément 24). Athens: École française d'Athènes.

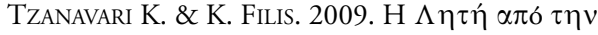

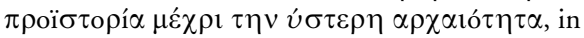
P. Adam-Veleni \& K. Tzanavari (ed.) To $A \rho \chi \alpha \iota \iota_{0 \gamma \iota \kappa}{ }^{\prime} E \rho \gamma o \sigma \tau \eta \nu M \alpha \kappa \varepsilon \delta o \nu i \alpha \kappa \alpha \iota$

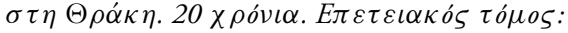
369-84. Thessaloniki: Ministry of Culture $\&$ University of Thessaloniki.

VAn ANDEL, T.H. \& C.N. RunNELS. 1995. The earliest farmers in Europe. Antiquity 69: 481-500.

Weninger B., E. Alram-Stern, E. Bauer, L. Clare, U. Danzeglocke, O. Jöris, C. Kubatzki, G. Rollefson, H. TODOROVA \& T. VAN ANDEL. 2006. Climate forcing due to the $8200 \mathrm{cal} \mathrm{yr} \mathrm{BP}$ event observed at Early Neolithic sites in the eastern Mediterranean. Quaternary Research 66: 401-20. 